\title{
Prophylactic Chimera Anterolateral Thigh/Vastus Lateralis Flap: Preventing Complications in High-Risk Head and Neck Reconstruction
}

\author{
Adriana Cordova, $M D,{ }^{*}$ Salvatore D’Arpa, MD, PhD, $\dagger$ Sara Di Lorenzo, MD, $\ddagger$ \\ Francesca Toia, MD, $\S$ Giuseppina Campisi, MD, /| and Francesco Moschella, MD $\|$
}

Purpose: In high-risk head and neck cases treated with tumor resection and associated radical neck dissection, orocutaneous fistulas and wound breakdowns in the neck are relatively frequent and can have serious consequences, such as carotid blowout syndrome (CBS), the need for salvage reoperations, and prolonged recovery time. The authors present the application of a prophylactic chimeric anterolateral thigh (ALT) and vastus lateralis (VL) flap to prevent complications.

Materials and Methods: A retrospective review was performed of a historical group (96 patients) of patients with head and neck cancer treated with tumor resection, radical neck dissection, and microsurgical reconstruction of the tumor site only and a prospective cohort (21 patients) in which a chimeric ALT-VL flap was used to simultaneously reconstruct the tumor site and sternocleidomastoid muscle to fill dead space and protect the carotid artery.

Results: The rate of complications was higher in the historical group: CBS occurred in $4.1 \%$ and orocutaneous fistulas in $11.5 \%$ of patients; $5.2 \%$ of patients required major salvage surgery for a wound complication. In the cohort group, no CBS or orocutaneous fistula occurred and no major salvage surgical procedure was needed.

Conclusions: Prophylactic ALT-VL flaps in high-risk head and neck cancers provide adequate and longlasting soft tissue coverage for the carotid artery, with minimal additional morbidity, and could be beneficial in preventing serious and life-threatening wound complications and the need for reoperation.

(C) 2014 American Association of Oral and Maxillofacial Surgeons

J Oral Maxillofac Surg 72:1013-1022, 2014

In high-risk head and neck cases treated with tumor resection and associated radical neck dissection, orocutaneous fistulas and wound breakdowns in the neck are relatively frequent. The wound complication rate for advanced cancers requiring microsurgical reconstruction varies from 20 to $47 \%$ in irradiated patients. ${ }^{1-3}$ In these cases, reoperation is often necessary to close the fistula and protect the neck vessels and is

Received from the Department of Surgical, Oncological, and Oral Sciences, University of Palermo, Palermo, Italy.

*Full Professor, Plastic and Reconstructive Surgery.

$\dagger$ Doctor, Plastic and Reconstructive Surgery.

$\ddagger$ Doctor, Plastic and Reconstructive Surgery.

$\S$ Doctor, Plastic and Reconstructive Surgery.

||Full Professor, Section of Oral Medicine "V. Margiotta."

ๆFull Professor, Plastic and Reconstructive Surgery.

This work was presented at the 22nd EURAPS meeting; Mykonos, Greece; June 2 to 4, 2011; and the 22nd meeting of the Italian Society for Microsurgery; Modena, Italy; October 1 to 3, 2011. responsible for longer hospitalization and a delay in adjuvant therapies. Wound complications also can lead to a devastating consequence, namely the carotid blowout syndrome (CBS), the threatened or acute rupture of the exposed carotid artery and its branches.

If deprived of the soft tissue coverage normally provided by the sternocleidomastoid muscle (SCM), when

Address correspondence and reprint requests to Dr Cordova: FEBOPRAS, Plastic and Reconstructive Surgery, Department of Surgical, Oncological, and Oral Sciences, Via del Vespro 129, 90127 Palermo, Italy; e-mail: adriana.cordova.unipa@gmail.com Received August 52013

Accepted November 112013

(C) 2014 American Association of Oral and Maxillofacial Surgeons

0278-2391/13/01421-3\$36.00/0

http://dx.doi.org/10.1016/i.joms.2013.11.010 
a wound breakdown occurs, the carotid artery is directly exposed and is subsequently at risk of rupture. This situation is facilitated by soft tissue necrosis in the neck and salivary fistulas, common complications after head and neck surgery.

CBS is classified into 3 types based on its clinical severity: acute, impending, and threatened ${ }^{4}$ (Table 1).

Impending and threatened CBS can be managed by using vascularized soft tissue coverage of the exposed carotid artery. The pectoralis major flap is the most frequently used flap for this purpose and is associated with intravascular stenting to repair the ruptured artery in impending cases. ${ }^{5-7}$

However, once the vessel wall has been damaged, long-term results of endovascular therapy are unfavorable for safety, stent patency, and hemorrhage prevention, and CBS has an average mortality rate of $40 \%$ and a morbidity of approximately $60 \%{ }^{8}$

The incidence of carotid rupture after radical neck dissection, with or without tumor resection, and multimodal therapy has been reported to be as high as 3 to $4 \%{ }^{9}$. Although the incidence might seem low, if the $40 \%$ mortality rate is taken into account, this problem is very relevant and deserves prevention.

\section{Table 1. DESCRIPTION AND PROGNOSIS OF} DIFFERENT TYPES OF CBS

\begin{tabular}{|c|c|c|}
\hline Types of CBS & Description & Prognosis \\
\hline Acute & $\begin{array}{l}\text { profuse hemorrhage } \\
\text { not controlled by } \\
\text { surgical packing } \\
\text { owing to carotid } \\
\text { rupture }\end{array}$ & $\begin{array}{l}\text { rapid evolution } \\
\text { death occurs } \\
\text { unless immediate } \\
\text { resuscitation and } \\
\text { closure of the } \\
\text { artery are } \\
\text { successfully } \\
\text { performed }\end{array}$ \\
\hline Impeding & $\begin{array}{l}\text { short episodes of } \\
\text { sentinel } \\
\text { hemorrhages that } \\
\text { resolve } \\
\text { spontaneously or } \\
\text { with simple } \\
\text { surgical packing }\end{array}$ & $\begin{array}{l}\text { if left untreated, } \\
\text { evolution into } \\
\text { complete rupture }\end{array}$ \\
\hline Threatened & $\begin{array}{l}\text { exposure of the } \\
\text { carotid artery } \\
\text { because of wound } \\
\text { breakdown or } \\
\text { neoplastic } \\
\text { invasion of the } \\
\text { carotid artery }\end{array}$ & $\begin{array}{l}\text { requires coverage } \\
\text { with well- } \\
\text { vascularized } \\
\text { tissue to prevent } \\
\text { rupture }\end{array}$ \\
\hline
\end{tabular}

Abbreviation: CBS, carotid blowout syndrome.

Cordova et al. Prophylactic Chimera ALT-VL Flap.J Oral Maxillofac Surg 2014
Prophylactic flaps have become a standard procedure in high-risk operations for the prevention of vessel exposure or of major wound complications requiring reoperation in groin surgery and in salvage laryngectomy. ${ }^{10-14}$ The same principle, transferring a flap prophylactically to prevent complications, can find broader use in head and neck cancer surgery. Since 2009 the authors have used a chimeric flap in selected primary head and neck cancers requiring microsurgical reconstruction and radical neck dissection with sacrifice of the SCM, to prevent CBS, orocutaneous fistulas, and the need for salvage operations. Two soft tissue islands are included in the flap based on the same pedicle (descending branch of the lateral circumflex femoral artery): a skin island (anterolateral thigh [ALT] flap) to repair the primary tumor site and a muscle island (vastus lateralis [VL]) as a muscular prophylactic flap to replace the SCM and cover and protect the carotid artery.

This report describes and discusses the indications, surgical technique, and outcomes of the prevention of surgery-related complications with a chimeric ALT-VL flap.

\section{Materials and Methods}

\section{PATIENT POPULATION}

A retrospective review was performed of a prospective cohort and a historical group of patients with head and neck cancer treated at the same institution (Department of Surgical, Oncological, and Oral Sciences, University of Palermo, Palermo, Italy). The study was approved by the local institutional review board.

All patients in the 2 groups underwent radical resection of a primary cancer of the lower half of the head and neck area (oral cavity, mandibular region, cheeks, or auricular and parotid regions) and met the following eligibility criteria:

- Microsurgical reconstruction with soft tissue required for reconstruction of the tumor site

- Concomitant radical neck dissection with required sacrifice of the SCM

- Having received neoadjuvant radiotherapy (RT) or radiochemotherapy (RCT) or being a candidate for adjuvant RT or RCT

Of 800 patients with head and neck cancers treated from 2000 to 2008, 96 (12\%) were selected according to these criteria and were treated with radical resection of the primary tumor, radical neck dissection with sacrifice of the SCM, and reconstruction of the tumor site with a free flap ( 58 radial forearm flaps, 36 ALT flaps, 1 VL flap, and 1 rectus abdominis flap). 
From January 2009 to January 2012, 21 patients were selected from 187 head and neck cancer cases (11.1\%). A chimeric ALT-VL muscle flap from the thigh was used to repair the primary tumor site and to simultaneously reconstruct the SCM (Fig 1). Twelve patients were men and 9 were women (mean age, $62 \mathrm{yr}$; range, 38 to $77 \mathrm{yr}$ ).

The tongue was the site most commonly involved ( 8 cases), followed by the cheek ( 4 cases), the retromolar trigone ( 4 cases), the floor of the mouth ( 3 cases), the mastoid area ( 1 case), and the auriculo-parotid region (1 case).

Three patients had preoperative neoadjuvant chemoradiation (Table 2, patients 1, 14, and 18). One patient had postoperative radiation only (Table 2 , patient 13). All other patients had adjuvant chemoradiation after surgery. Data from these patients are presented in Table 2.

The 2 groups showed a similar distribution in age, gender, tumor stage, comorbidities, and smoking and were compared for the rate of wound breakdown, orocutaneous fistulas and CBS, need for salvage operations, and hospital stay.

\section{SURGICAL TECHNIQUE}

Flap planning does not differ substantially from planning a conventional ALT flap.

The flap inset is of no particular challenge when a transmandibular approach is used or the defect is located in the skin. The ALT flap should be inset before vascular anastomoses and sutured to the defect; then, the pedicle is passed into the neck under direct vision.

When primary cancer surgery has been performed through an intraoral approach with a pull-through technique, a wide tunnel, depending on the skin flap size, will have to be made and the flap delivered from the neck to the mouth. Any excess tension on the perforator must be avoided in these cases. After the skin flap is sutured to the defect, the muscle is temporarily wrapped in moist gauze and transferred to cover the vessels once the anastomoses have been completed. Its cut ends are sutured to the aponeurotic stumps of the SCM (Fig 2). The skin island of the flap is used for monitoring. Nerve coaptation is not necessary for coverage. The muscle is not meant to restore function, but to provide prophylactic coverage to the vessels. Muscle atrophy from denervation will not cause loss of coverage, but rather, only fibrous and adipose degeneration, as discussed later in the article.

\section{Results}

The complication data of the 2 groups are presented in Table 3. In the historical group (2000 to 2008), 28 patients $(29.2 \%)$ developed a wound complication and 5 patients $(5.2 \%)$ required major salvage surgery.
Wound dehiscence occurred in 17 patients (17.7\%), 13 (13.5\%) of whom were treated conservatively or with a minor surgical procedure for secondary wound closure, whereas 4 patients (4.2\%) developed a CBS. There were 2 cases $(2.1 \%)$ of threatened CBS, one of which occurred during postoperative RT; these cases required a pectoralis major flap to protect the exposed carotid artery. The other 2 patients developed acute CBS and died of this complication. An orocutaneous fistula occurred in 11 patients (11.5\%), one of which required a salvage pectoralis major flap. Other complications were infection (2\%), hematoma (1\%), partial flap necrosis (1\%), and total flap loss (1\%). The mean hospital stay was 17 days (range, 10 to 45 days).

In the prospective cohort (2009 to 2012), the wound complication rate was $14.3 \%$ (3 patients), and no major salvage surgery was needed to cover exposed neck vessels or to repair an orocutaneous fistula. There were $3(14 \%)$ postoperative wound dehiscences that were managed with local wound care or secondary closure. No orocutaneous fistula or CBS occurred.

Despite early pharmacologic thrombolysis, ${ }^{15}$ partial flap necrosis was observed in 1 case (4.8\%). The cutaneous ALT flap of the chimeric flap in the oral cavity died owing to perforator compression or stretching within the tunnel connecting the neck to the oral cavity. A salvage radial forearm flap was performed 5 days after the initial procedure and healed uneventfully.

No complete flap necrosis or other complication was observed. One tracheocutaneous fistula occurred and was treated with a local flap. The remaining $17 \mathrm{pa}-$ tients healed uneventfully within 1 month after the operation with a single major surgical procedure.

The VL flap provided adequate and long-lasting soft tissue coverage for the carotid artery as shown by postoperative CT scans (Fig 3). Two years after the operation, stable coverage was still present, with the muscle maintaining an average thickness of $2.23 \mathrm{~cm}$ (range, 1.7 to $2.8 \mathrm{~cm}$ ). Four patients died of metastatic disease and 1 of heart failure. After a mean follow-up of 32 months (range, 18 to 32 months), the remaining 16 patients were alive and free from disease. The mean hospital stay was 13 days (range, 10 to 32 days).

\section{Discussion}

Local complications, such as wound breakdown, orocutaneous fistulas, infection, and delayed healing, are relatively frequent in these cases owing to the contaminated intraoral environment, saliva permeation, comorbidities, and poor nutritional status of these patients. In advanced-stage head and neck cancers, adjuvant and neoadjuvant radiation with or without chemotherapy compromise tissue vascularity and increase the risk of wound complications. Furthermore, such complications require a salvage operation 

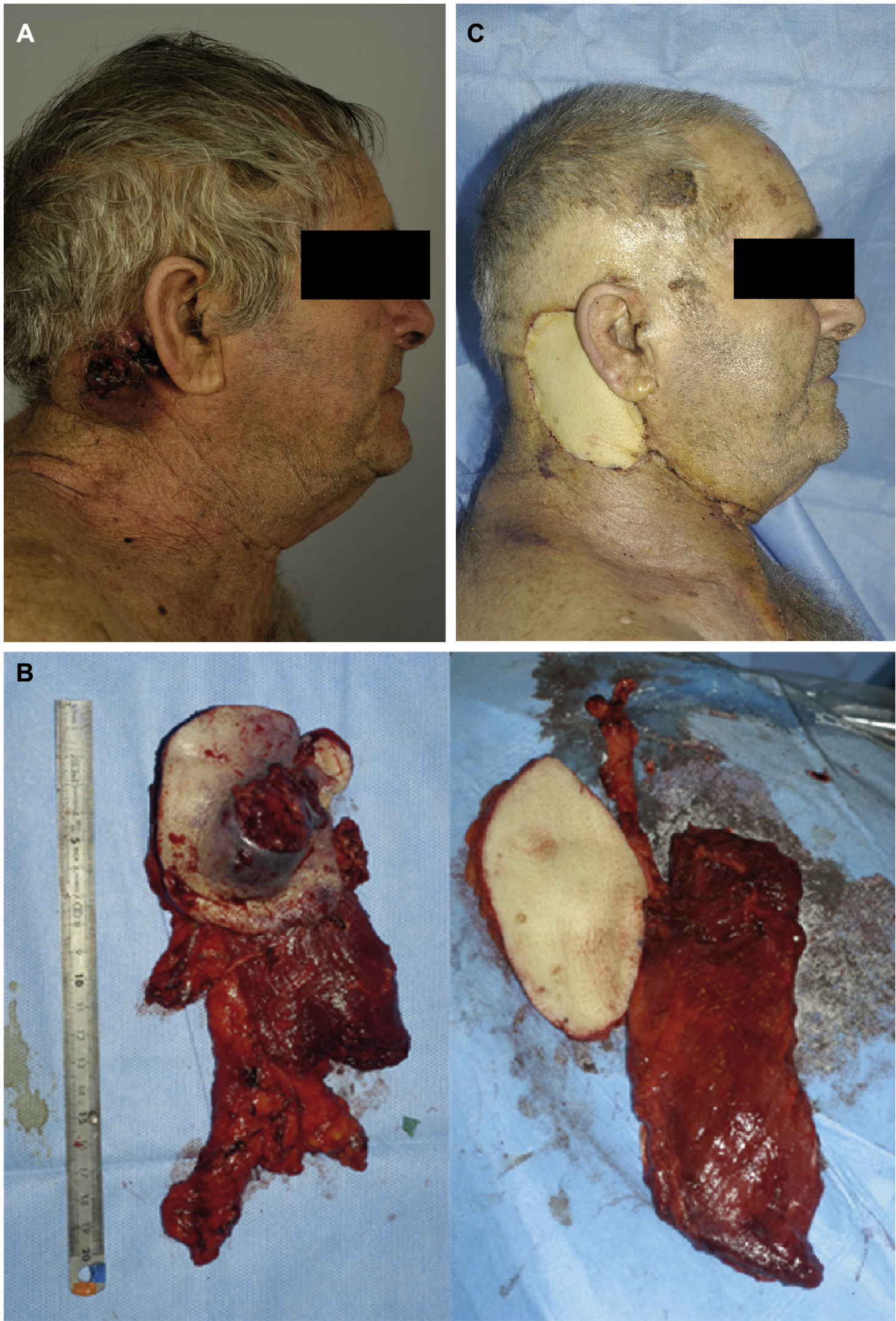

FIGURE 1. Case 7. A, Preoperative photograph displays a retroauricular squamous cell carcinoma with direct invasion of the sternocleidomastoid muscle. B, Photographs show the resected specimen (leff) and the flap used for reconstruction (right). This is a clear example of how anatomic such a reconstruction can be by closely reproducing the features of the resected tissues. $C$, Postoperative result 1 month after operation. 
Table 2. PROSPECTIVE COHORT (2009 TO 2012)

\begin{tabular}{|c|c|c|c|c|c|}
\hline $\begin{array}{l}\text { Patient } \\
\text { Number }\end{array}$ & $\begin{array}{l}\text { Gender/ } \\
\text { Age }\end{array}$ & Cancer/Location & Surgical Approach & $\begin{array}{l}\text { Neoadjuvant/ } \\
\text { Adjuvant } \\
\text { Treatment }\end{array}$ & Complications \\
\hline 1 & $\mathrm{M} / 42$ & $\begin{array}{l}\text { SCC G2/retromolar } \\
\text { trigone }\end{array}$ & $\begin{array}{l}\text { lateral emivisor approach } \\
\text { wide resection and RND } \\
\text { ALT-VL free chimeric flap }\end{array}$ & pre-op CRT & $\begin{array}{l}\text { neck skin necrosis with } \\
\text { exposure of muscular } \\
\text { component of chimera } \\
\text { flap }\end{array}$ \\
\hline 2 & M/77 & SCC G2/tongue & $\begin{array}{l}\text { C.TM approach } \\
\text { emiglossectomy and RND } \\
\text { ALT-VL free chimeric flap }\end{array}$ & post-op CRT & $\begin{array}{l}\text { tracheocutaneous fistula } \\
\text { secondary surgery: local } \\
\text { flap }\end{array}$ \\
\hline 3 & M/76 & SCC G3/tongue & $\begin{array}{l}\text { C.TM access } \\
\text { subtotal glossectomy and RND } \\
\text { ALT-VL free chimeric flap }\end{array}$ & post-op CRT & $\begin{array}{l}\text { superficial neck skin } \\
\text { necrosis }\end{array}$ \\
\hline 4 & $\mathrm{~F} / 75$ & SCC G2/tongue & $\begin{array}{l}\text { transoral approach } \\
\text { emiglossectomy and RND } \\
\text { ALT-VL free chimeric flap }\end{array}$ & post-op CRT & none \\
\hline 5 & M/59 & $\begin{array}{l}\text { SCC G2/tongue and floor } \\
\text { of mouth }\end{array}$ & $\begin{array}{l}\text { C.TM approach } \\
\text { emiglossectomy, partial } \\
\text { pelvectomy, RND } \\
\text { ALT-VL free chimeric flap }\end{array}$ & post-op CRT & none \\
\hline 6 & $M / 45$ & SCC G2/cheek & $\begin{array}{l}\text { transoral approach } \\
\text { wide excision and RND } \\
\text { ALT-VL free chimeric flap }\end{array}$ & post-op CRT & $\begin{array}{l}\text { superficial neck skin } \\
\text { necrosis }\end{array}$ \\
\hline 7 & M/71 & SCC G3/mastoid region & $\begin{array}{l}\text { wide excision and RND } \\
\text { ALT-VL free chimeric flap }\end{array}$ & post-op CRT & none \\
\hline 8 & $\mathrm{~F} / 75$ & $\begin{array}{l}\text { SCC G1/retromolar } \\
\text { trigone }\end{array}$ & $\begin{array}{l}\text { C.TM approach } \\
\text { wide excision and RND } \\
\text { ALT-VL free chimeric flap }\end{array}$ & post-op CRT & none \\
\hline 9 & $\mathrm{~F} / 60$ & SCC G2/tongue & $\begin{array}{l}\text { transoral approach } \\
\text { emiglossectomy and RND } \\
\text { ALT-VL free chimeric flap }\end{array}$ & post-op CRT & $\begin{array}{l}\text { partial necrosis of ALT } \\
\text { flap } \\
\text { secondary surgery: } \\
\text { forearm flap }\end{array}$ \\
\hline 10 & $\mathrm{~F} / 58$ & SCC G2/cheek & $\begin{array}{l}\text { transoral approach } \\
\text { wide excision and RND } \\
\text { ALT-VL free chimeric flap }\end{array}$ & post-op CRT & none \\
\hline 11 & $\mathrm{M} / 73$ & $\begin{array}{l}\text { SCC G3/tongue and floor } \\
\text { of mouth }\end{array}$ & $\begin{array}{l}\text { C.TM approach } \\
\text { emiglossectomy, partial } \\
\text { pelvectomy, RND } \\
\text { ALT-VL free chimeric flap }\end{array}$ & post-op CRT & $\begin{array}{l}\text { infection } \\
\text { conservative treatment }\end{array}$ \\
\hline 12 & $\mathrm{~F} / 65$ & SCC G3/tongue & $\begin{array}{l}\text { C.TM approach } \\
\text { emiglossectomy and RND } \\
\text { ALT-VL free chimeric flap }\end{array}$ & post-op CRT & none \\
\hline 13 & F/66 & SCC G3/cheek & $\begin{array}{l}\text { transoral approach } \\
\text { wide excision and RND } \\
\text { ALT-VL free chimeric flap }\end{array}$ & post-op RT & none \\
\hline 14 & $\mathrm{M} / 70$ & $\begin{array}{l}\text { SCC G3/tongue and floor } \\
\text { of mouth }\end{array}$ & $\begin{array}{l}\text { C.TM approach } \\
\text { wide excision and RND } \\
\text { ALT-VL free chimeric flap }\end{array}$ & pre-op CRT & none \\
\hline 15 & $\mathrm{~F} / 38$ & $\begin{array}{l}\text { SCC G3/tongue, } \\
\text { retromolar trigone, } \\
\text { tonsil }\end{array}$ & $\begin{array}{l}\text { emivisor lateral approach } \\
\text { wide excision and RND } \\
\text { ALT-VL free chimeric flap }\end{array}$ & post-op CRT & none \\
\hline 16 & M/65 & $\begin{array}{l}\text { SCC G2/floor of mouth } \\
\text { and alveolar ridge }\end{array}$ & $\begin{array}{l}\text { transoral approach } \\
\text { wide excision and RND } \\
\text { ALT-VL free chimeric flap }\end{array}$ & post-op CRT & none \\
\hline 17 & M/39 & $\begin{array}{l}\text { SCC G3/auricular-parotid } \\
\text { region }\end{array}$ & $\begin{array}{l}\text { wide excision and RND } \\
\text { ALT-VL free chimeric flap }\end{array}$ & post-op CRT & none \\
\hline
\end{tabular}


Table 2. Cont'd

\begin{tabular}{|c|c|c|c|c|c|}
\hline $\begin{array}{l}\text { Patient } \\
\text { Number }\end{array}$ & $\begin{array}{c}\text { Gender/ } \\
\text { Age }\end{array}$ & Cancer/Location & Surgical Approach & $\begin{array}{l}\text { Neoadjuvant/ } \\
\text { Adjuvant } \\
\text { Treatment }\end{array}$ & Complications \\
\hline 18 & M/71 & $\begin{array}{l}\text { SCC G3/tongue and } \\
\text { retromolar trigone }\end{array}$ & $\begin{array}{l}\text { C.TM approach } \\
\text { wide excision and RND } \\
\text { ALT-VL free chimeric flap }\end{array}$ & pre-op CRT & none \\
\hline 19 & $\mathrm{~F} / 72$ & $\begin{array}{l}\text { SCC G2/cheek and } \\
\text { alveolar ridge }\end{array}$ & $\begin{array}{l}\text { transoral approach } \\
\text { wide excision and RND } \\
\text { ALT-VL free chimeric flap }\end{array}$ & post-op CRT & none \\
\hline 20 & M/68 & SCC G3/floor of mouth & $\begin{array}{l}\text { composite transmandibular } \\
\text { resection and RND } \\
\text { ALT-VL free chimeric flap }\end{array}$ & post-op CRT & none \\
\hline 21 & $\mathrm{~F} / 63$ & SCC/floor of mouth & $\begin{array}{l}\text { C.TM approach } \\
\text { wide resection and RND } \\
\text { ALT-VL free chimeric flap }\end{array}$ & post-op CRT & none \\
\hline
\end{tabular}

Abbreviations: ALT, anterolateral thigh; C.TM, conservative transmandibular; CRT, chemoradiation; F, female; M, male; post-op, postoperative; pre-op, preoperative; RND, radical neck dissection; RT, radiotherapy; SCC, squamous cell carcinoma; VL, vastus lateralis.

Cordova et al. Prophylactic Chimera ALT-VL Flap. J Oral Maxillofac Surg 2014.

with the associated morbidity, ${ }^{5,6}$ prolonged hospital stay, longer time to recovery, and subsequent delay in adjuvant treatments, which can be very detrimental to patients with advanced disease. The likelihood of a wound complication requiring reoperation in highrisk cases exceeds $20 \%^{3,5,6,8,12-14}$ and justifies the adoption of prophylactic measures to avoid it.

Prophylactic flaps have become a common procedure in high-risk cases in vascular surgery and head and neck surgery. Muscle flaps represent a standard procedure in groin surgery after node dissections or after vascular surgery to prevent vascular exposure. $^{10,11}$ In head and neck surgery, prophylactic transfer of a pedicled or free flap is used to prevent wound complications and vessel exposure after total laryngectomy. ${ }^{12-14}$ In these settings, prophylactic flaps decrease postoperative complications rates, hospital stay, need for reoperation, and need for antibiotics and speed up patients' recovery. ${ }^{10-14}$

High-risk head and neck cancers requiring microsurgical reconstruction have exactly the same problems. The reported incidences of wound complications vary from 20 to $47 \%$ in irradiated patients and reoperations are necessary in up to $22 \%$ of cases. ${ }^{1-3}$

Prophylactic coverage of the carotid artery is also effective in minimizing a relatively infrequent but lifethreatening complication, namely CBS, which is more frequent in the threatened form and reported to be as frequent as $4 \%{ }^{4,8}$ In these cases, when facing a wound breakdown in the cervical area, if the carotid is protected by well-vascularized muscle, conservative treatment or minor procedures can allow wound closure without major salvage operations.
The authors believe that these figures justify the introduction of prophylactic measures to decrease the incidence of complications and reoperations in highrisk cases. The use of prophylactic muscle flaps in this setting has been reported by other investigators. ${ }^{7,12-14}$

In the present series, the rate of wound breakdown requiring only conservative treatment and minor revision surgery was similar in the historical and prospective groups (13.5\% and $14.4 \%$, respectively). However, an additional $4.1 \%$ of patients with a wound breakdown developed a CBS in the historical group, with a related mortality of $50 \%$, whereas the carotid artery was well protected in the cohort treated with a prophylactic chimeric ALT-VL flap and no CBS occurred (Fig 4). The difference in the rate of orocutaneous fistulas was even greater ( $11.5 \%$ vs $0 \%)$.

No major salvage procedure after a wound complication was needed in the prospective cohort, whereas it was necessary in $5.2 \%$ of patients in the historical group. The mean hospital stay was slightly longer in the historical group (17 vs 13 days), owing to the longer hospitalization required in case a major reoperation was performed (mean, 30 days; range, 20 to 45 days), which led to a delay in adjuvant treatments. Although a statistical analysis was not performed owing to the small samples, the difference rates between the 2 groups suggest that the prophylactic muscle flap was effective in preventing those complications.

The pectoralis major flap represents the first choice of flap for the treatment of threatened CBS and orocutaneous fistulas, but its use as a prophylactic muscle flap was reported by Schneider et al ${ }^{\top}$ to fill dead space 


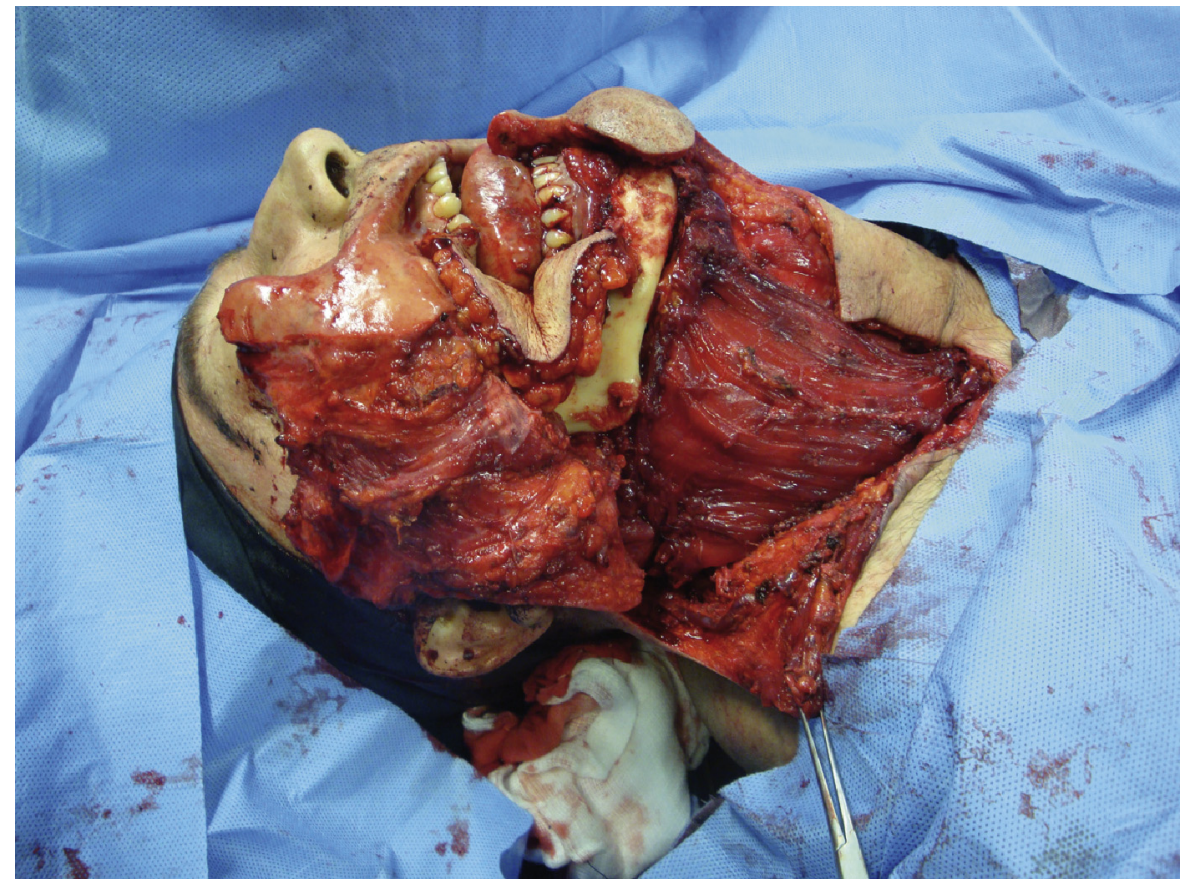

FIGURE 2. Case 1. Intraoperative view of 42 -year-old patient who had undergone chemoradiation before the operation for a squamous cell carcinoma. Resection involved the retromolar trigone, part of the tongue, and the hard and soft palate en bloc with radical neck dissection, marginal mandibulectomy, and partial maxillectomy. Photograph shows the flap after completion of the anastomosis and partial inset. The anterolateral thigh has been tunneled to the mouth and the vastus lateralis has been used to completely cover the carotid as the sternocleidomastoid muscle did.

Cordova et al. Prophylactic Chimera ALT-VL Flap. J Oral Maxillofac Surg 2014.

and protect the carotid artery after radical neck dissection combined with a concurrent free tissue transfer.

The chimeric ALT-VL flap has the advantages of not requiring a second flap or a new donor site and of avoiding the significant morbidity correlated with pectoralis major flap harvest. Only a minimal modification of the microsurgical reconstructive planning is needed, which allows for filling of dead space and protection of the carotid artery. The ALT flap has become a standard flap for head and neck surgery and can be a valid

\section{Table 3. COMPLICATION RATE, SECONDARY SURGERY, AND TREATMENT-RELATED MORTALITY IN THE HISTORICAL (2000 TO 2008) AND PROSPECTIVE (2009 TO 2012) GROUPS}

\begin{tabular}{|c|c|c|c|c|c|c|c|c|}
\hline \multirow[b]{2}{*}{ Complications } & \multicolumn{2}{|c|}{ Complication Rate } & \multicolumn{2}{|c|}{$\begin{array}{l}\text { Major Salvage } \\
\text { Procedures }\end{array}$} & \multicolumn{2}{|c|}{ Minor Reoperations } & \multicolumn{2}{|c|}{$\begin{array}{c}\text { Treatment-Related } \\
\text { Mortality }\end{array}$} \\
\hline & $\begin{array}{l}2000-2008 \\
\text { Series, } \\
\text { n (\%) }\end{array}$ & $\begin{array}{l}2009-2012 \\
\text { Series, } \\
\text { n (\%) }\end{array}$ & $\begin{array}{l}2000-2008 \\
\text { Series, } \\
\text { n (\%) }\end{array}$ & $\begin{array}{l}2009-2012 \\
\text { Series, } \\
\text { n (\%) }\end{array}$ & $\begin{array}{l}2000-2008 \\
\text { Series, } \\
\text { n (\%) }\end{array}$ & $\begin{array}{l}2009-2012 \\
\text { Series, } \\
\text { n (\%) }\end{array}$ & $\begin{array}{l}2000-2008 \\
\text { Series, } \\
\text { n (\%) }\end{array}$ & $\begin{array}{l}\text { 2009-2012 } \\
\text { Series, } \\
\text { n (\%) }\end{array}$ \\
\hline $\begin{array}{l}\text { Overall wound } \\
\text { complications }\end{array}$ & $28(29.2)$ & $3(14.3)$ & $5(5.2)$ & $0(0)$ & $5(5.2)$ & $1(4.8)$ & $2(2.1)$ & $0(0)$ \\
\hline $\begin{array}{l}\text { Wound breakdown } \\
\text { (no CBS) }\end{array}$ & $13(13.5)$ & $3(14.3)$ & $0(0)$ & $0(0)$ & $5(5.2)$ & $1(4.8)$ & $0(0)$ & $0(0)$ \\
\hline $\begin{array}{l}\text { Wound breakdown } \\
\text { (CBS) }\end{array}$ & $4(4.2)$ & $0(0)$ & $2(2.1)$ & $0(0)$ & $0(0)$ & $0(0)$ & $2(2.1)$ & $0(0)$ \\
\hline Orocutaneous fistula & $11(11.5)$ & $0(0)$ & $3(3.1)$ & $0(0)$ & $0(0)$ & $0(0)$ & $0(0)$ & $0(0)$ \\
\hline $\begin{array}{l}\text { Other complications } \\
\text { (infection, } \\
\text { hematoma, flap } \\
\text { necrosis) }\end{array}$ & $6(6.3)$ & $2(9.5)$ & $3(3.1)$ & $1(4.8)$ & $1(1)$ & $1(4.8)$ & $0(0)$ & $0(0)$ \\
\hline
\end{tabular}

Abbreviation: CBS, carotid blowout syndrome.

Cordova et al. Prophylactic Chimera ALT-VL Flap. J Oral Maxillofac Surg 2014. 


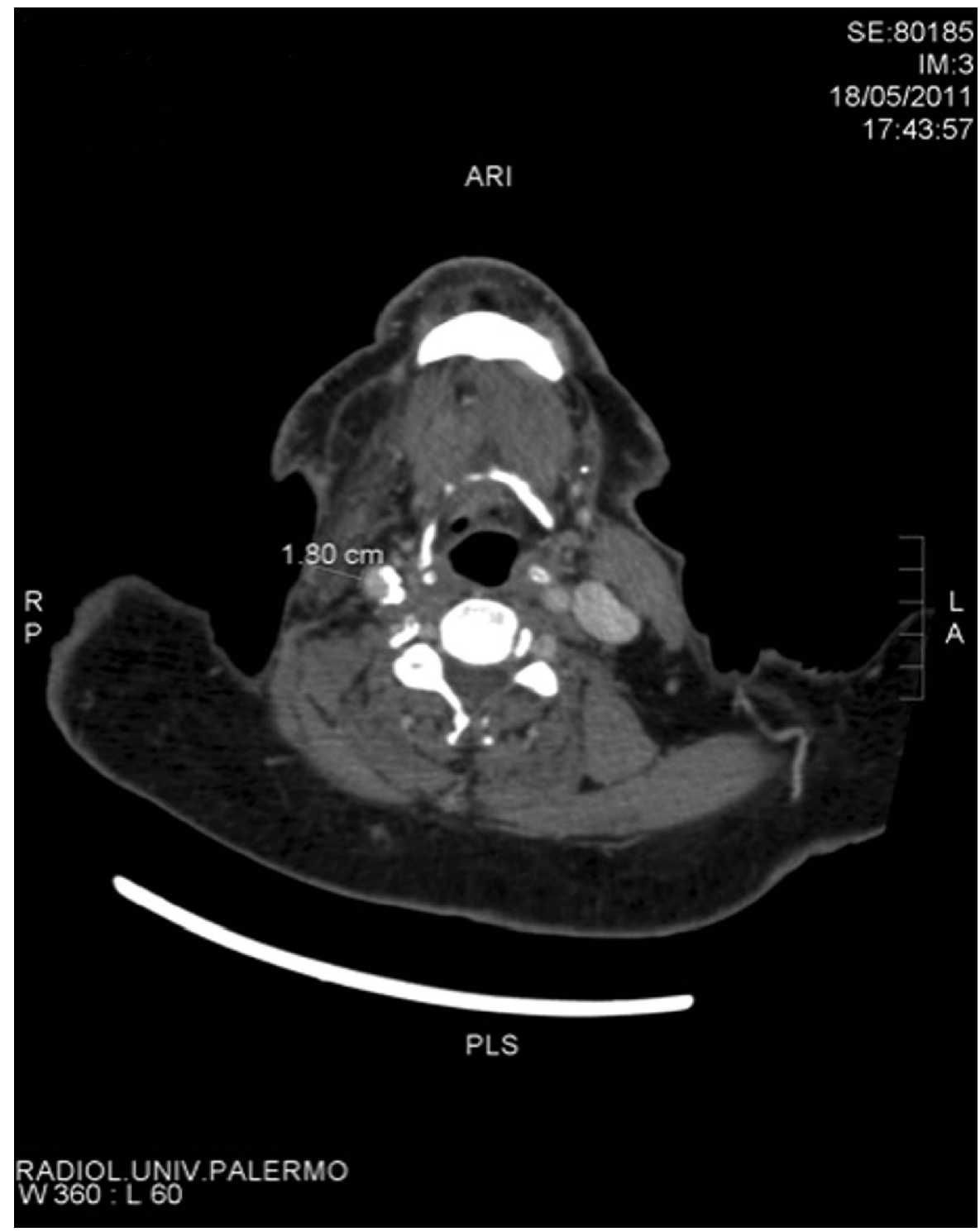

FIGURE 3. Computed tomogram obtained 2 years after operation. Although the patient has undergone radiotherapy and 2 years of denervation have caused muscle atrophy, an adequately thick tissue layer still protects the carotid artery.

Cordova et al. Prophylactic Chimera ALT-VL Flap. J Oral Maxillofac Surg 2014.

alternative to the radial forearm flap, and chimeric flaps from the lateral circumflex femoral system have many applications in head and neck surgery, ${ }^{16-19}$ even for the prevention of orocutaneous fistulas. ${ }^{20}$

Transfer of a chimeric flap, including a portion of the VL muscle, adds some time ( 0.5 hour on average) to the operation, carries little additional risk because the 2 flaps are supplied by a single pedicle (no additional anastomoses), and causes little additional morbidity to the thigh. Harvesting of the VL muscle has been associated with minimal donor-site morbidity, similar to that resulting after ALT flap transfer. ${ }^{21,22}$

The study has some limitations. A statistical analysis was not possible because of the small size and different sample of the historical and prospective groups. Differences in radiation oncology techniques in the 2 groups were not evaluated and could have influenced the complication rate: newer RT techniques (such as intensity-modulated RT) are likely to carry a lower additional risk of CBS compared with older techniques; in addition, differences in timing (adjuvant vs neoadjuvant) could play a role in decreasing wound complications. However, only a minority of head and neck cancers requires radical neck dissection, including the SCM, and only a small number will develop a CBS. These characteristics of the population make it difficult to prospectively evaluate the potential of prophylactic flaps and to obtain large series for statistical validation. No prospective study is available in the literature, although prophylactic reconstruction with an additional flap has been reported ${ }^{7}$ and is a currently discussed practice for the prevention of life-threatening 

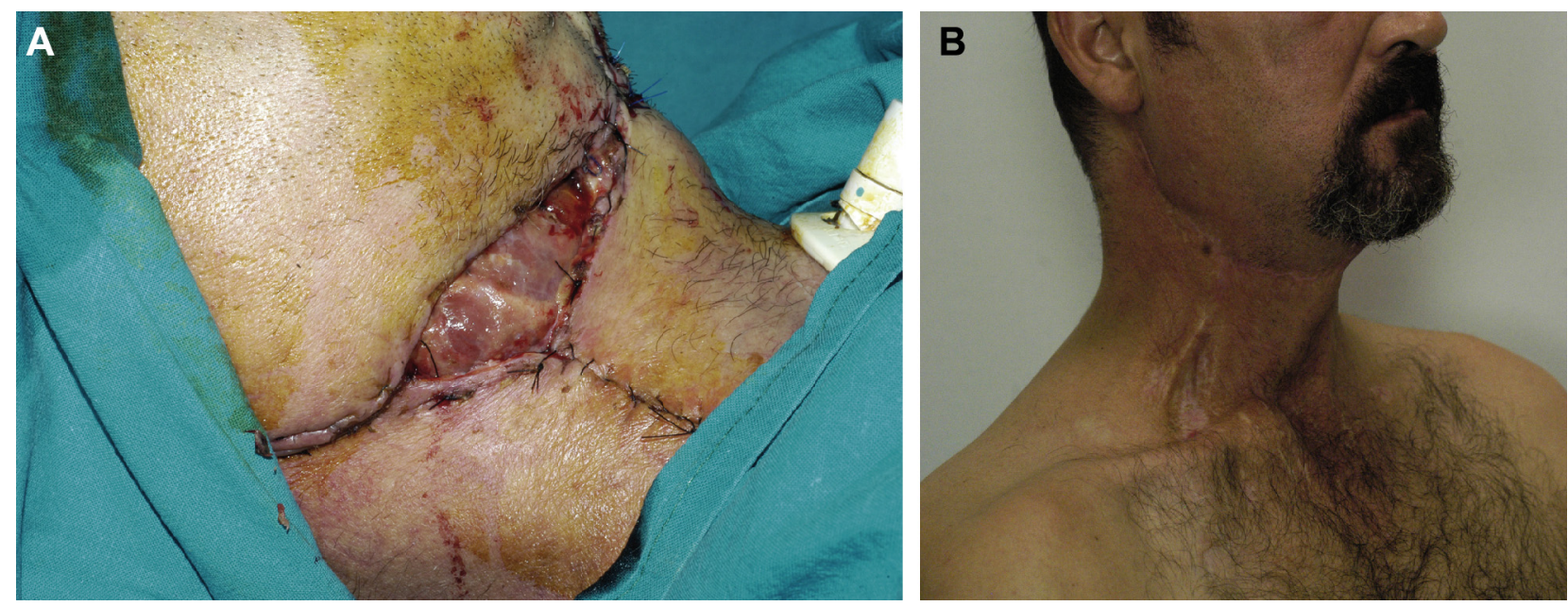

FIGURE 4. $A$, Wound breakdown 1 month after operation. Without appropriate coverage of the carotid, this situation would have resulted in a threatened blowout syndrome. The vastus lateralis muscle is visible through the wound, protects the carotid artery, and provides a wellvascularized bed that allows the wound to heal spontaneously. $B$, One-year postoperative view shows how the wound has healed without further intervention.

Cordova et al. Prophylactic Chimera ALT-VL Flap. J Oral Maxillofac Surg 2014.

complications. Although the present study does not allow for statistical conclusions, the difference in the occurrence rate of orocutaneous fistulas and CBS between the 2 groups ( $11.5 \%$ and $4.1 \%$, respectively) suggests a protective role of the technique, whose morbidity is significantly lower than that of the combination of a free flap with a pectoralis major flap.

A larger radial forearm or ALT flap could be partly deepithelialized using the de-epithelialized soft tissue portion for carotid artery protection. However, this approach significantly restricts freedom in the flap inset, cannot be used for all defect locations, and does not allow for a "like-with-like" reconstruction. When used for intraoral reconstruction, the connection to the cervical portion of the flap will restrict movement of the intraoral part by adding weight and bonding the flap to the neck, and the continuity between the 2 portions of the flap could facilitate the formation of orocutaneous fistulas.

Some other criticisms may be made. The 3-dimensional inset of the flap is somewhat more complicated than in a conventional flap when a transoral approach is used, because of the need for skin flap tunneling from the neck to the mouth. It might be argued that a denervated muscle atrophies and thus cannot provide long-lasting coverage. However, atrophy is not disappearance, but rather, fibrofatty degeneration owing to loss of the neuromuscular junctions and of the muscular architecture and subsequent replacement with fibrous and fatty tissue, as depicted by postoperative CT scans.

The ALT-VL chimeric flap is a valid option for simultaneous repair of the primary tumor site and replacement of the SCM in selected patients affected by advanced head and neck cancer of the lower half of the head and neck area who satisfy the following criteria of inclusion:

- Microsurgical reconstruction of the primary cancer with soft tissue required, ie, flaps

- Radical neck dissection with sacrifice of the SCM

- Neoadjuvant or adjuvant RT or RCT

In this selected high-risk population, reconstruction with a prophylactic chimeric ALT-VL flap provides adequate and long-lasting soft tissue coverage for the carotid artery with minimal additional morbidity and could be beneficial in decreasing the need for reoperations, speeding up recovery, decreasing time to adjuvant therapies, and minimizing the risk of life-threatening complications such as CBS. The authors believe this prophylactic approach deserves to become part of the reconstructive algorithm of advanced-stage cancers of the lower half of the head and neck area.

\section{References}

1. Bianchi B, Copelli C, Ferrari S, et al: Free flaps: Outcomes and complications in head and neck reconstructions. J Craniomaxillofac Surg 37:438, 2009

2. Simon C, Bulut C, Federspil PA, et al: Assessment of peri- and postoperative complications and Karnofsky-performance status in head and neck cancer patients after radiation or chemoradiation that underwent surgery with regional or free-flap reconstruction for salvage, palliation, or to improve function. Radiat Oncol 6:109, 2011

3. Bourget A, Chang JTC, Wu DBS, et al: Free flap reconstruction in the head and neck region following radiotherapy: A cohort study identifying negative outcome predictors. Plast Reconstr Surg $127: 1901,2011$

4. Chang C, Lirng JF, Luo CB, et al: Carotid blowout syndrome in patients with head and neck cancers: Reconstructive 
management by self-expandable stent-grafts. AJNR Am J Neuroradiol 28:181, 2007

5. Patak KA, Viallet NR, Nason RW: Sternocleidomastoid muscle interposition to prevent carotid artery blowout. J Surg Oncol 98:565, 2008

6. Righi PD, Weisberger EG, Slakes SR: The pectoralis major myocutaneous flap: Applications in head and neck reconstruction. Am J Otolaryngol 19:96, 1998

7. Schneider DS, Wu V, Wax MK: Indications for pedicled pectoralis major flap in a free tissue transfer practice. Head Neck 34:1106, 2012

8. Powitzky R, Vasan N, Krempl G, et al: Carotid blow out in patients with head and neck cancer. Ann Otol Rhinol Laryngol $119: 476,2010$

9. Chang FC, Ling JF, Luo CB, et al: Patients with head and neck cancers and associated postirradiated carotid blowout syndrome: Endovascular therapeutic methods and outcomes. J Vasc Surg 47:936, 2008

10. Fischer JP, Nelson JA, Mirzabeigi MN, et al: Prophylactic muscle flaps in vascular surgery. J Vasc Surg 55:1081, 2012

11. Fisher JP, Nelson JA, Rohrbach JI, et al: Prophylactic muscle flaps in vascular surgery: The Penn Groin Assessment Scale. Plast Reconstr Surg 129:940e, 2012

12. Fung K, Teknos TN, Vandenberg CD, et al: Prevention of wound complications following salvage laryngectomy using free vascularized tissue. Head Neck 2:425, 2007

13. Gil Z, Gupta A, Kummer B, et al: The role of pectoralis major muscle flap in salvage total laryngectomy. Arch Otolaryngol Head Neck Surg 135:1019, 2009
14. Albirmawy OA: Prevention of postlaryngectomy pharyngocutaneous fistula using a sternocleidomastoid muscle collar flap. J Laryngol Otol 121:253, 2007

15. D'Arpa S, Cordova A, Moschella F: Pharmacological thrombolysis: One more weapon for free-flap salvage. Microsurgery 25:477, 2005

16. Posch NAS, Mureau MAM, Flood SJ, et al: The combined free partial vastus lateralis with anterolateral thigh perforator flap reconstruction of extensive composite defects. Br J Plast Surg $58: 1095,2005$

17. Adler N, Dorafshar AH, Agarwall JP, et al: Harvesting the lateral femoral circumflex chimera free flap: Guidelines for elevation. Plast Reconstr Surg 123:918, 2009

18. Kerawala CJ: Reconstruction of defects after hemiglossectomy using a chimeric vastus lateralis free flap. Br J Oral Maxillofac Surg 47:126, 2009

19. Rubino C, Faenza M, Muzzeddu GP, et al: Compartment syndrome at the fibula flap's donor site and salvage by anterolateral thigh chimeric flap. Microsurgery 32:657, 2012

20. Rodríguez-Vega JM, Trillo Bohajar E, Ruiz Alonso E, et al: Refining the anterolateral thigh free flap to prevent orocervical fistula in head and neck reconstruction. Plast Reconstr Surg 114:174, 2004

21. Hanasono MM, Skoracki RJ, Yu P: A prospective study of donorsite morbidity after anterolateral thigh fasciocutaneous and myocutaneous free flap harvest in 220 patients. Plast Reconstr Surg 125:209, 2010

22. Lee MJ, Yun IS, Rah DK, et al: Lower extremity reconstruction using vastus lateralis myocutaneous flap versus anterolateral thigh fasciocutaneous flap. Arch Plast Surg 39:367, 2012 